\title{
Synthesis and photo electrochemical characterization of an extended $\Pi$-conjugated heteroleptic ruthenium (ii) complex
}

\begin{abstract}
A new extended $\pi$-conjugate heteroleptic ruthenium(II) complex (m-HRD-1) that contains a 4,4'-bis-2-(5(3,5-di-tert-butylphenyl)thiophene-2-yl)vinyl)2,2'-bipyridine as ancillary ligand, 4,4'-dicaboxy-2,2'-bipyridine as anchoring group, and two thiocyanate ligands in its molecular structure have been designed, synthesized and characterized by $\mathrm{CHN}$, Mass, 1H-NMR, UV-Vis, and fluorescence spectroscopies as well as cyclic voltammetry. Electrochemical and theoretical studies showed that the LUMO of the sensitizer is above $\mathrm{TiO}_{2}$ conduction band and the HOMO is below the redox potential of the electrolyte. This new sensitizer was tested in dye-sensitized solar cells using liquid redox couple $\left(\mathrm{I}^{-} / \mathrm{I}_{3}^{-}\right)$and its performance was compared to the standard sensitizer N719.
\end{abstract}

Keywords: dye sensitized solar cells, extended $\pi$-conjugation, bipyridine, heteroleptic, redox electrolyte

\author{
Volume I Issue 2 - 2017 \\ Tejaswi Jella, ${ }^{1,2}$ P Selvaraj, ${ }^{3}$ Hari M \\ Upadhyaya, ${ }^{4}$ Tapas K Mallick, ${ }^{3}$ S Senthilarasu, ${ }^{3}$ \\ Lingamallu Giribabu ${ }^{\prime, 2}$ \\ 'Inorganic \& Physical Chemistry Division, CSIR-Indian Institute \\ of Chemical Technology, India \\ ${ }^{2}$ Academy of Scientific and Innovative Research (AcSIR), India \\ ${ }^{3}$ Environment and Sustainability Institute (ESI), University of \\ Exeter, UK \\ ${ }^{4}$ Department of Mechanical, Brunel University, UK
}

\author{
Correspondence: I. Senthilarasu Sundaram, Lecturer in \\ Renewable Energy, Environment and Sustainability Institute, \\ University of Exeter, Penryn, Room No: 01.27, Cornwall TR I0 \\ 9EZ, UK, Tel +44 (0) I 326259486 \\ Email S.Sundaram@exeter.ac.uk \\ 2. Lingamallu Giribabu, Inorganic \& Physical Chemistry Division, \\ CSIR-Indian Institute of Chemical Technology, Uppal Road, \\ Tarnaka, Hyderabad-500007, Telangana, India, \\ Email giribabu@iict.res.in
}

Received: September 27, 2017 | Published: October 06, 2017

\section{Introduction}

Dye-Sensitized Solar Cells (DSSCs) are one of the rising hopes for the future renewable energy sources among the excitonic photovoltaics because of their encouraging power conversion efficiencies of $>10 \%$ for metal free dyes, $>11 \%$ for metal complex and $13 \%$ for porphyrin based sensitizers. ${ }^{1-6}$ As sensitizers take part in the absorption of solar radiation and injection of electrons into the conduction band of semiconductors, extensive research has been focused on the design of efficient and durable sensitizers. Several dyes have been investigated such as metal complexes, metal-free organic dyes, tetra pyrrolic porphyrin and phthalocyanine based sensitizers. ${ }^{7-16}$ Among them, the most successful charge transfer sensitizers are ruthenium based dye molecules, because of their strong and broad metal to ligand charge transfer absorption bands, the stability of their oxidized form and longevity of photo excited states. Grätzel and co-workers have reported $>11 \%$ efficiency with cis-di(thiocyanato)-bis [2,2'-bipyridyl 4,4'-dicarboxylic acid] ruthenium(II)(N3) and trithiocyanato-4,4'4'tricarboxy-2,2':6',2"-terpyridine ruthenium(II) (the black dye) as sensitizers. ${ }^{17}$ Many efforts have been made to design the ligands of ruthenium complexes to improve the spectral response to near IR region and device performance. By substituting the two long alkyl chains on the bipyridyl ligand (Z907), Zakeeruddin and co workers achieved impressive stability under both thermal and light conditions. ${ }^{18}$ However, the molar extinction coefficient of sensitizer is somewhat lower than that of the standard N-719 dye. Thus, extended $\pi$-conjugation has been introduced into the ligands to improve the molar extinction coefficient. For instance, Z910, which contains 3 -methoxystyryl on bipyridine ligand, exhibited $10.2 \%$ efficiency and remarkable stability. ${ }^{19}$ Based on these conclusions several dyes have been developed using different substituents on styrene moiety of bipyridyl ligand- K19, K77, HRD and electron donors on bipyridine ligands such as triphenylamine, carbazole and coumarin etc. ${ }^{20-24} \mathrm{By}$ using electron donating substrates charge recombination decreased drastically, as this forms long charge separated state lifetimes. Wu and co-workers incorporated alkyl thiophene substituted bipyridine as an ancillary ligand on the ruthenium metal complex (CYC-B1, $\mathrm{C} 101$ ), as a consequence, the MLCT band has shifted to the red region and the energy levels of metal center can be raised for better charge injection and recombination. ${ }^{25,26}$ Our group is also engaged in the design and development of efficient heteroleptic Ru (II) polypyridyl complexes. $^{22-29}$ For instance, we have introduced 3, 5-di-tertbutyl phenyl group on extended $\pi$-conjugation of bipyridine ligand (HRD-1). HRD-1 has shown a conversion efficiency of $5.77 \%$ and impressive performance in thermal and light soaking studie. ${ }^{22}$ The objective of this work is to re-design and synthesis HRD-1 complex by introducing thiophene moiety between the 3,5-di-tert-butyl phenyl group, also extending $\pi$-conjugation of bipyridine ligand to get heteroleptic $\mathrm{Ru}(\mathrm{II})$ (m-HRD-1) complex in order to further improve the absorption properties and also to tune the energy levels. Moreover, characterization of the complex by various spectroscopic techniques and its DSSC performance using liquid $\mathrm{I}^{-} / \mathrm{I}^{-}$redox couple. The structure of m-HRD-1 and its ligand are shown in Figure 1. 


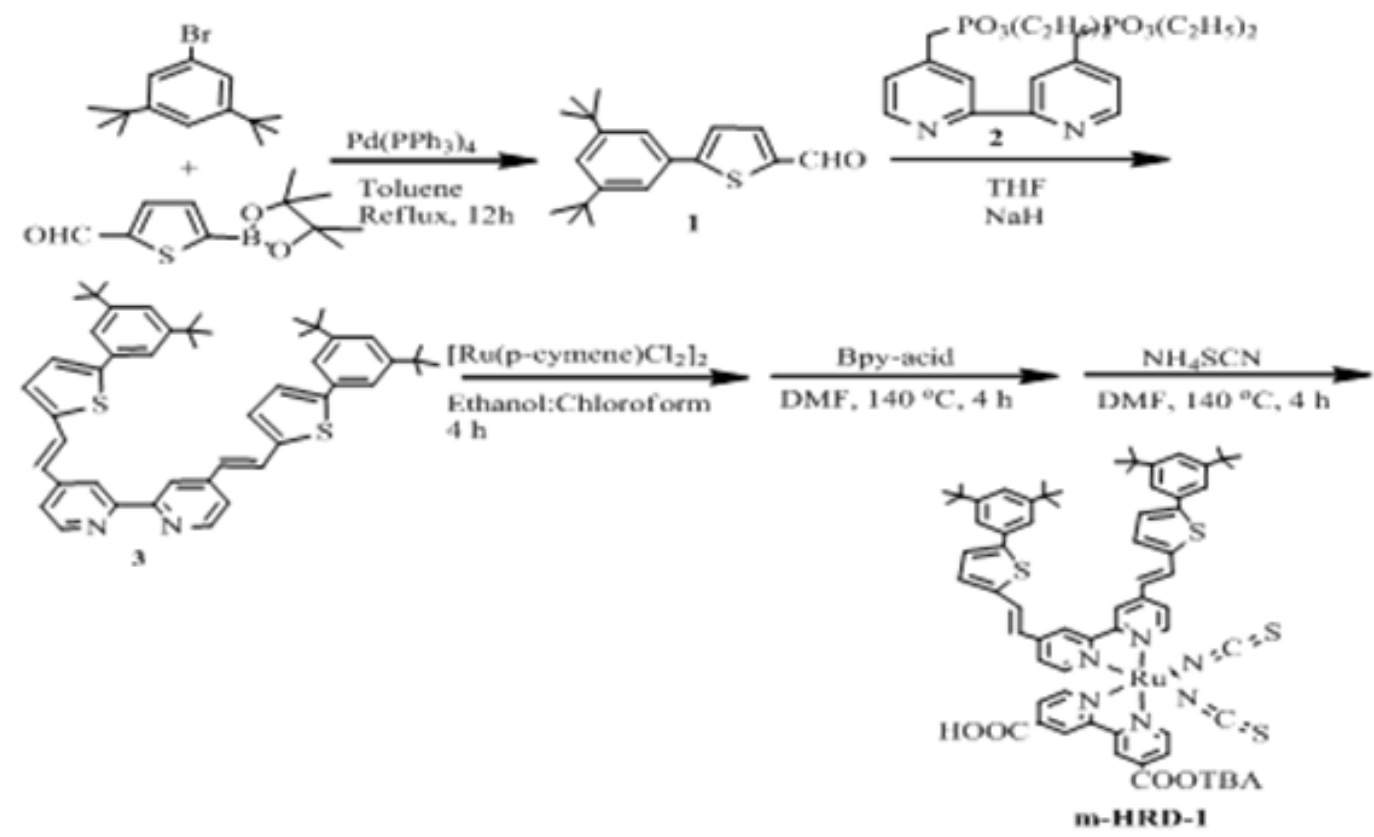

Figure I Synthetic scheme of m-HRD-I.

\section{Experimental methods}

All chemicals and solvents were purchased either from Sigma Aldrich or BDH (India) and purified prior to use. The compound 4, 4'-diethyl ester phosphonate-2,2'-bipyridine (2) was synthesized as per literature methods. ${ }^{27}$

\section{Synthesis}

Synthesis of 5-(3,5-di-tert-butylphenyl)thiophene-2carbaldehyde(1): 3,5-di-tert-butyl bromobenzene ( $942 \mathrm{mg}, 3.5 \mathrm{mmol}$ ) was dissolved in $40 \mathrm{ml}$ of dry toluene, to which $\mathrm{CsCO}_{3}(393.6 \mathrm{mg}, 1.2$ $\mathrm{mmol}), \mathrm{Pd}\left(\mathrm{PPh}_{3}\right)_{4}(0.25$ equivalents $)$ and 5-(4,4,5,5-tetramethyl-1,3,2dioxaborolan-2-yl)thiophene-2-carbaldehyde (1.86 g, $7.8 \mathrm{mmol})$ were added. The reaction mixture was then refluxed under nitrogen atmosphere for $12 \mathrm{~h}$. After cooling to RT, the crude mixture was purified using silica gel column EtOAc/Hex (1:4 v/v) to provide the desired product ( $90 \%$ yield). Elemental analysis of Anal. Calcd. For $\mathrm{C}_{19} \mathrm{H}_{24} \mathrm{OS} \%$ (300.460): C, 75.95; H, 8.05; N, 5.32. Found: C, 75.92; $\mathrm{H}, 8.03$; N, 5.30. ESI-MS (m/z): $\mathrm{C}_{19} \mathrm{H}_{24}$ OS [300.460]: M 301 (100\%). ${ }^{1} \mathrm{HNMR}\left(\mathrm{CDCl}_{3}, \delta \mathrm{ppm}\right): 9.85(\mathrm{~s}, 1 \mathrm{H}), 7.70(\mathrm{~m}, 1 \mathrm{H}), 7.45(\mathrm{~m}, 3 \mathrm{H})$, $7.35(\mathrm{~m}, 1 \mathrm{H}), 1.35(\mathrm{~s}, 18 \mathrm{H})$.

Synthesis of 4,4'-bis-2-(5(3,5-di-tert-butylphenyl)thiophene-2yl)vinyl)2,2'-bipyridine (3): This ligand was synthesized by using Wittig-Horner's reaction. ${ }_{30} \mathrm{NaH}(360 \mathrm{mg}, 15 \mathrm{mmol})$ was added to a solution of 2,2'-bipyridine-4,4'-diphosphonate $(1.5 \mathrm{~g}, 3.5 \mathrm{mmol})$ and 5-(3,5-di-tert-butylphenyl)thiophene-2-carbaldehyde (1) (0.51 g, 7.8 $\mathrm{mmol}$ ) in $150 \mathrm{ml}$ of dry tetrahydrofuran (THF). The resulting mixture was refluxed overnight under nitrogen atmosphere. The reaction mixture was allowed to cool to room temperature and filtered the compound. The filtrate was concentrated and the solid was washed with methanol and dried to obtain the desired product in pure form of $75 \%$ yield. Elemental analysis of Anal. Calcd. For $\mathrm{C}_{50} \mathrm{H}_{56} \mathrm{~N}_{2} \mathrm{~S}_{2} \%$ (749.132): C, 80.17; H, 7.54; N, 3.74. Found: C, 80.20; H, 7.52; N, 3.70. ESI-MS (m/z): $\mathrm{C}_{50} \mathrm{H}_{56} \mathrm{~N}_{2} \mathrm{~S}_{2}$ [740.132]: M $750(100 \%) .{ }^{1} \mathrm{H}$ NMR
$\left(\mathrm{CDCl}_{3}, \delta \mathrm{ppm}\right): 8.65(\mathrm{~d}, 2 \mathrm{H}), 8.50(\mathrm{~s}, 2 \mathrm{H}), 7.55(\mathrm{~d}, 2 \mathrm{H}), 7.42(\mathrm{~s}, 4 \mathrm{H})$, $7.35(\mathrm{~s}, 2 \mathrm{H}), 7.32(\mathrm{~d}, 2 \mathrm{H}), 7.20(\mathrm{~d}, 2 \mathrm{H}), 7.15(\mathrm{~d}, 2 \mathrm{H}), 6.95(\mathrm{~d}, 2 \mathrm{H})$, $1.42(\mathrm{~s}, 36 \mathrm{H})$.

Synthesis of $\mathrm{Ru}(\mathrm{L})(\mathrm{p}$-cymene $)(\mathrm{Cl})_{2}$ : A mixture of $3(0.38 \mathrm{~g}, 1.25$ $\mathbf{m m o l})$ and $\left[\mathbf{R u}(\mathbf{C l})_{2}-(\mathbf{p} \text {-cymene })\right]_{2}$ in ethanol: chloroform $(8: 2 \mathrm{v} / \mathrm{v})$ was refluxed for 4 hours under nitrogen atmosphere. Evaporation of the solvent under reduced pressure produced the pure complexes as an orange solid.

Synthesis of m-HRD-1: The above p-cymene complex (1.24 mmol) and 4, 4'-dicarboxy-2, 2'-bipyridine, (L) (0.303 g, $1.24 \mathrm{mmol}$ ) in anhydrous DMF $(75 \mathrm{ml})$ were heated to $140{ }^{\circ} \mathrm{C}$ for 4 hours under nitrogen atmosphere and in the dark. $\mathrm{NH}_{4} \mathrm{SCN}(1,5 \mathrm{~g}, 19.7 \mathrm{mmol})$ was then added to the mixture and heating was continued for $4 \mathrm{~h}$. After cooling to room temperature, DMF was evaporated and water was added. The resulting purple solid was filtered and washed with water. The crude complex in basic methanol [with tetrabutyl ammonium hydroxide (TBAOH)] was further purified on a Sephadex LH20 column with methanol as eluent. The main band was collected, concentrated, and precipitated with dilute acidic methanol to obtain pure desired complex. Elemental analysis of Anal. Calcd. For $\mathrm{C}_{80} \mathrm{H}_{99} \mathrm{~N}_{7} \mathrm{O}_{4} \mathrm{RuS}_{4} 1$ (TBA) \% (1452.02): C, 66.17; H, 6.87; N, 6.75. Found: C, 66.20; H, 6.20; N, 6.72. ESI-MS (m/z): $\mathrm{C}_{80} \mathrm{H}_{99} \mathrm{~N}_{7} \mathrm{O}_{4} \mathrm{RuS}_{4}$ 1(TBA) [1452.02]: $\mathrm{M}+11453$ (5\%).

\section{Characterization methods}

The optical absorption spectra were recorded on a Shimadzu (Model UV-3600) spectrophotometer. Steady state fluorescence spectra were recorded using a Spex model Fluorlog-3 spectrofluorometer for solutions having optical density at the wavelength of excitation $\left(1_{\mathrm{ex}}\right)$ »0.11. ${ }^{1} \mathrm{H}$ NMR spectra were obtained at $300 \mathrm{MHz}$ using a Brucker 300 Avance NMR spectrometer running X-WIN NMR software. The chemical shifts are related to tetramethylsilane (TMS). The Fourier transform IR (FTIR) spectra of all the samples were measured using 
a Thermo Nicolet Nexus 670 spectrometer. Cyclic- and differential pulse voltammetric measurements were performed on a PC-controlled $\mathrm{CH}$ instruments model CHI620C electrochemical analyzer. Cyclic voltammetric experiments were performed in $1 \mathrm{mM}$ dye solution in acetonitrile at a scan rate of $100 \mathrm{mV} / \mathrm{s}$ using $0.1 \mathrm{M}$ tetrabutyl ammoniumperchlorate (TBAP) as a supporting electrolyte. A glassy carbon electrode, a standard calomel electrode (SCE), and a plantinum wire were used as the working electrode, reference electrode and counter electrode respectively. After a cyclic voltammogram (CV) had been recorded, ferrocene was added, and a second voltammogram was measured. Thermogravimetric measurements were carried out on a Mettler Toledo TGA/SDTA 851e instrument at a heating rate of $10^{\circ} \mathrm{C} \mathrm{min}{ }^{-1}$ with $10 \mathrm{mg}$ of sample under nitrogen atmosphere.

\section{Computational methodlogy}

Ground state geometries optimized in the gas phase with the $\mathrm{PBEO}^{31}$ functional with $\mathrm{LanL} 2 \mathrm{DZ}^{32-34}$ with effective-core potential (ECP) were used for $\mathrm{Ru}$, and for rest of the elements $6-311+\mathrm{G}(\mathrm{d}, \mathrm{p})$ was used. ${ }^{35,36}$ The conductor-like polarisable continuum model $(\mathrm{C}-\mathrm{PCM})^{37}$ was used to optimize the geometries in acetonitrile. TDDFT (time-dependent density functional theory) calculations were performed on the PBE0 optimized geometries using CAM-B3LYP 38 with the above mentioned mixed basis set to calculate the vertical excitation energies, since it has been previously reported by many researchers that the CAM-B3LYP functional gives reliable results for MLCT. ${ }^{39}$ All the calculations were done in Gaussian 09..$^{40}$

\section{Dye cell preparation}

The detailed $\mathrm{TiO}_{2}$ photoelectrode (area: ca. $0.28 \mathrm{~cm} 2$ ) preparation was described in our earlier studies. ${ }^{41,42}$ Briefly, nanocrystalline $\mathrm{TiO}_{2}$ films of 8-8.5 $\mu \mathrm{m}$ thickness were deposited onto transparent conducting glass (fluorine-doped stannic oxide layer, sheet resistance of 8-10 $\Omega$ / $\mathrm{cm}^{2}$ ). Then a scattering layer of $\sim 4 \mu \mathrm{m}$ thickness of $400 \mathrm{~nm}$ anatase $\mathrm{TiO}_{2}$ particles was deposited by screen-printing method. These films were gradually sintered at $500^{\circ} \mathrm{C}$ for $30 \mathrm{~min}$. The heated electrodes were impregnated with a $0.04 \mathrm{M}$ titanium tetrachloride solution in water saturated desiccator for $30 \mathrm{~min}$ at $70{ }^{\circ} \mathrm{C}$ then washed with distilled water and ethanol. The electrodes were annealed again at 500 ${ }^{\circ} \mathrm{C}$ for $30 \mathrm{~min}$ and then allowed to cool to $50{ }^{\circ} \mathrm{C}$ before dipping them into the dye solution. The $\mathrm{TiO}_{2}$ electrodes were soaked overnight in an ethanolic solution of $1 \times 10^{-6} \mathrm{MN} 719$ dye (cis-diisothiocyanato-bis (2,2'bipyridyl-4,4'dicarboxylato)ruthenium(II)bis(tetrabutylammonium)) (Solaronix SA), sandwiched with a platinised conducting counter electrode prepared on FTO substrate using a Surlyn frame (Solaronix SA), filled with the electrolyte through a hole in the counter electrode and sealed. The iodide/tri-iodide electrolyte comprising $0.4 \mathrm{M} \mathrm{LiI}$, $0.4 \mathrm{M}$ tetrabutylammonium iodide (TBAI), and $0.04 \mathrm{M}$ I2 dissolved in $0.3 \mathrm{M} \mathrm{N}$-methylbenzimidazole $(\mathrm{NMB})$ in acetonitrile $(\mathrm{ACN})$ and 3-methoxypropionitrile (MPN) solvent mixture at volume ratio of 1:1 was used. The photovoltaic performances of the assembled devices were meaured under $1000 \mathrm{~W} / \mathrm{m}^{2}$ of light from a Wacom AAA continuous solar simulator (model: WXS-210S-20, AM1.5G).

\section{Results and discussion}

The details of the synthetic strategy adopted for the synthesis of m-HRD-1 are shown in Figure 1. The compound 5-(3,5-ditert-butylphenyl)thiophene-2-carbaldehyde was synthesized by adopting Suzuki coupling between 3,5-di-tert-butyl bromobenzene and 5-(4,4,5,5-tetramethyl-1,3,2-dioxaborolan-2-yl)thiophene2-carbaldehyde. ${ }^{43}$ Bpy-phosphonate was synthesized as per the literature methods. ${ }^{27}$ We have adopted Wittig-Horner's reaction for the introduction of $\mathrm{C}=\mathrm{C}$ double bond was introduced at 4,4 ' positions of the bipyridine ligand using Bpy-phosphonate and $1 .{ }^{30}$ The ligand Bpythio-butyl (L) was characterized by various spectroscopic techniques that include elemental analysis, Mass, IR and 1H NMR spectroscopies (See Supporting Information). The ligand $\mathrm{L}$ and $\left[\mathrm{RuL} \text { (p-cymene) } \mathrm{Cl}_{2}\right]_{2}$ complex by refluxing in ethanol: chloroform mixture to get the chloro derivative of m-HRD-1 complex. Finally, the m-HRD-1 complex was synthesized by refluxing chloro derivative with Bpy-acid and aq. ammonium thiocyanate in DMF and following by spehadex column purification. Preliminarily, m-HRD-1 was characterized by elemental analysis and ESI-MS spectroscopies. The presences of a molecular ion peak at $1453(\mathrm{~m} / \mathrm{z})$ in ESI-MS spectrum confirms one TBA molecule in its molecular structure (See Supporting Information).

\section{Optical properties}

Figure 2 reveals the absorption spectra of m-HRD-1 in ethanol and the corresponding data are presented in Table 1. The absorption bands between 450 to $550 \mathrm{~nm}$ regions can be ascribed to the metal to ligand charge transfer transitions in singlet manifold (1MLCT). The absorption maximum of m-HRD-1 is centered at $538 \mathrm{~nm}$ with a molar extinction coefficient of 15,338 M-1 cm-1. The MLCT band of m-HRD-1 is bathochromically shifted when compared to HRD1 , probably due to the extended $\pi$-conjugation. Intraligand $\pi-\pi^{*}$ transitions bipyridine ligand are located at $300 \mathrm{~nm}$. We have also measured absorption spectra of m-HRD-1 on an opaque $\mathrm{TiO}_{2}$ film (6 $\mu \mathrm{m}$ thick). The absorption spectra in solution and on $\mathrm{TiO}_{2}$ were similar except for a slight red shift in absorption maxima due to the interaction of anchoring groups to the nanocrystalline $\mathrm{TiO}_{2}$ surface. The emission spectrum of m-HRD-1 was measured in ethanol solvent at room temperature and presented in Figure 2. The complex m-HRD-1 has shown emission maxima at $755 \mathrm{~nm}$, when excited at MLCT band of m-HRD- complex. We have observed quenched emission spectra, when m-HRD- 1 complex adsorbed on a $6 \mu \mathrm{m}$ thick nanocrystalline $\mathrm{TiO}_{2}$ layer, as a consequence of electron injection from the excited state of $\mathrm{Ru}$ (II) complex to the conduction band of $\mathrm{TiO}_{2}$. From the absorption and emission spectra, the singlet state (E0-0) energy of m-HRD-1 and HRD-1 are $1.94 \& 1.90 \mathrm{eV}$, respectively. Quenched emission spectrum of m-HRD-1 was observed when adsorbed.

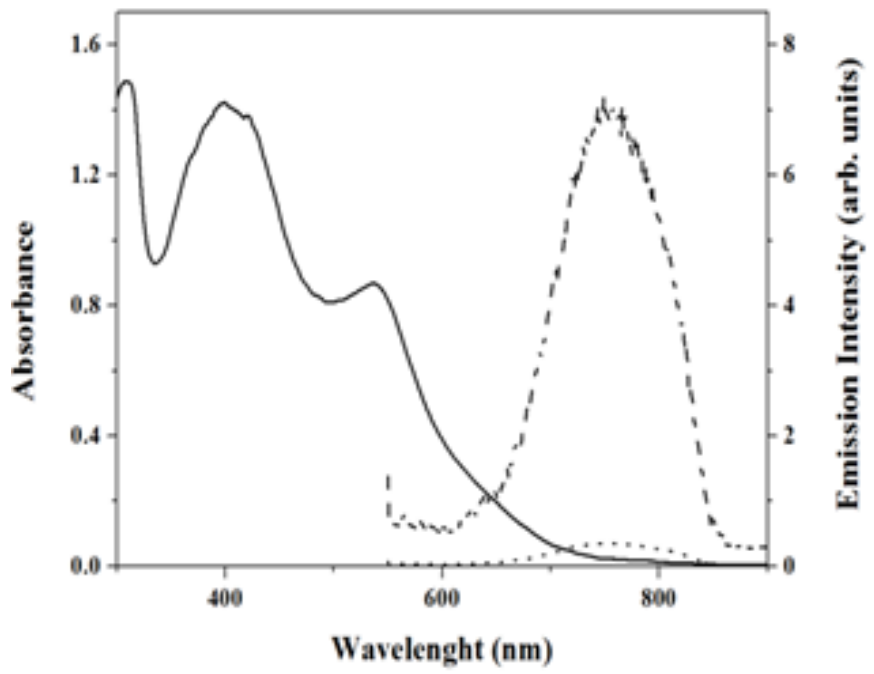

Figure 2 Electronic absorption (-) and emission (------) spectra of m-HRD-I in ethanol solvent. Emission (.........) spectra m-HRD-I adsorbed onto a $2 \mu \mathrm{m}$ thick $\mathrm{TiO}_{2}$ film. 
Table I UV-Visible, emission and electrochemical data

\begin{tabular}{llllll} 
Sensitizer & $\lambda_{\mathbf{m a x}}, \mathbf{n m}, \varepsilon\left(\mathbf{m o l}^{-\mathbf{1}} \mathbf{c m}^{-\mathbf{1}}\right)^{\mathbf{a}}$ & $\lambda_{e m}, \mathbf{n m}{ }^{b}$ & $\mathbf{E}_{1 / 2} \mathbf{V}$ vs. SCE $\mathbf{~ O x ~ R e d ~}$ & $\mathbf{E}_{0.0}, \mathbf{e V}^{\mathbf{d}}$ & $\mathbf{E}_{\text {ox }}^{*}$ \\
\hline m-HRD-I & $538(15,338)$ & 755 & $0.67-0.95$ & 1.94 & -1.27 \\
HRD-I & $543(19,300)$ & 720 & $0.75-0.94$ & 1.9 & -1.15 \\
\hline
\end{tabular}

aSolvent: ethanol, Error limits: $\lambda_{\max }, \pm \mathrm{nm}, \varepsilon \pm 10 \%$.

bSolvent: ethanol, $\lambda_{\max }, \pm \mathrm{I} \mathrm{nm}$.

'Solvent: DMF, Error limits: $\mathrm{E}_{1 / 2} \pm 0.03 \mathrm{~V}, 0$. I MTBAP.

${ }^{d}$ Error limits: $0.05 \mathrm{eV}$.

\section{Electrochemical properties}

The redox potential of m-HRD-1 was evaluated by using cyclic and differential pulse voltammetric techniques in DMF solvent with $0.1 \mathrm{M}$ tetrabutyl ammonium perchlorate as a supporting electrolyte and their data was compared to the standard sensitizer HRD-1 in Table 1 (Figure 3). From the table it is clear that m-HRD-1 undergoes one electron reversible oxidation at $0.67 \mathrm{~V}$ vs. SCE. The oxidation process can be readily assigned to the $\mathrm{Ru}$ (II)/ $\mathrm{Ru}$ (III) redox couple. It also undergoes two reductions at -0.95 , corresponding to the reduction of ancillary bipyridine ligands. The excited oxidation potential of m-HRD-1 is $1.27 \mathrm{~V}$, which is above the conduction band of $\mathrm{TiO}_{2}(41)$.
To identify the electronic distribution of the m-HRD-1 sensitizer, we performed DFT calculations of its electronic ground state using mPW1PW91 method for the geometry optimization with LANL2DZ basis function on $\mathrm{Ru}$ and 6-31g (d) basis function on $\mathrm{C}, \mathrm{H}, \mathrm{N}, \mathrm{O}$ and S.It can be seen from Figure 4, HOMO, HOMO-1, HOMO-2, HOMO-3 \& HOMO-4 are the electrons delocalized over the Ru (II) metal and -NCS ligand. The LUMO, LUMO+1, LUMO+2, LUMO+3 $\& \mathrm{LUMO}+4$ are $\pi^{*}$ orbitals delocalized over the bipyridine carboxylic acid ligand facilitating electron injection from the excited state of the m-HRD-1 sensitizer to the conduction band of $\mathrm{TiO}_{2}$. These results are in line with other ruthenium (II) polypyridyl complexes reported in the literature. ${ }^{44,45}$

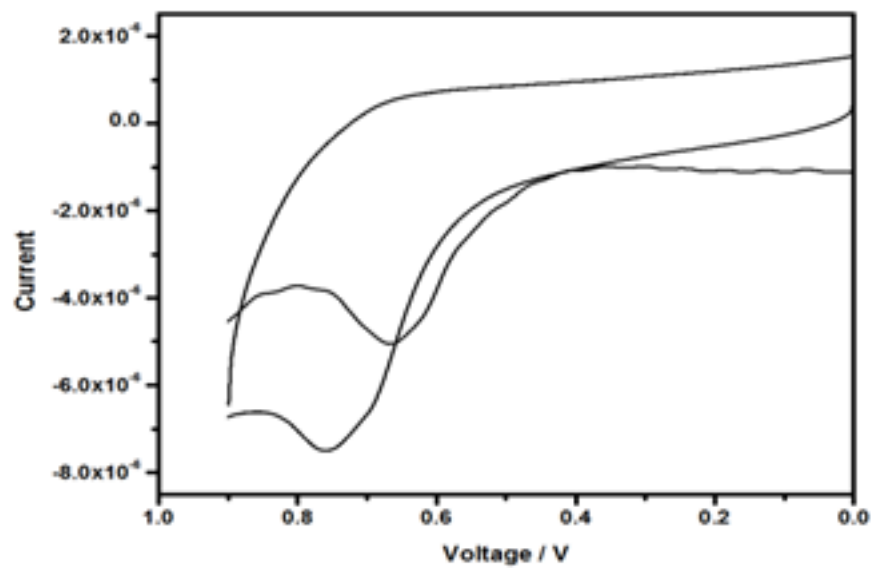

Figure 3 Cyclic and differential pulse voltammogramme of m-HRD-I.
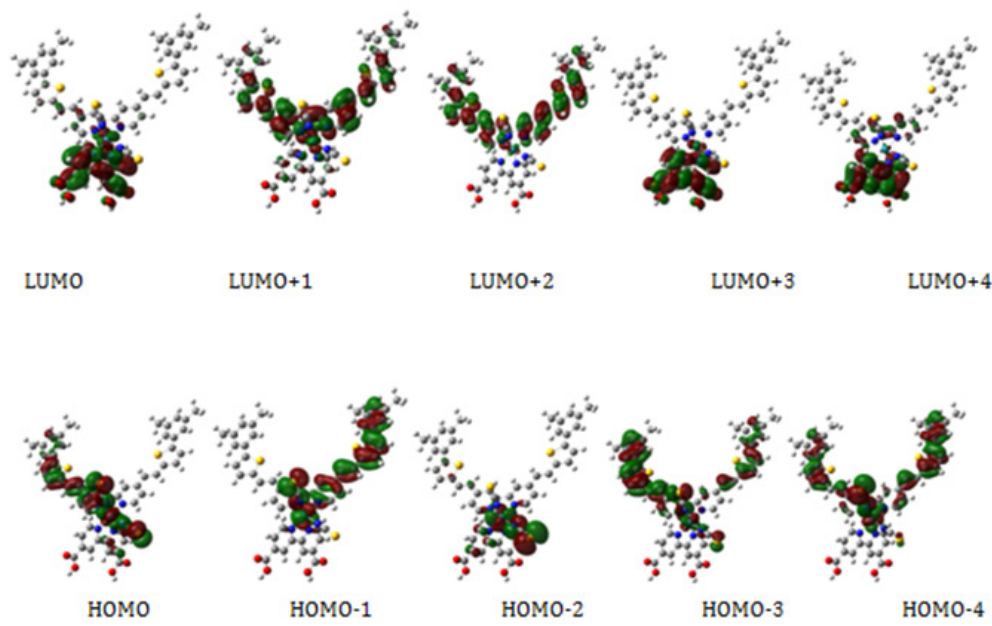

Figure 4 Molecular orbital and spatial orientation of m-HRD-I. 


\section{Photovoltaic properties}

The performance of the DSSCs was evaluated based on their steady state current- voltage characteristics. Figure 5 depicts the photocurrent density versus photovoltage $(\mathrm{J}-\mathrm{V})$ curves of the DSSCs based on standard N719 and m-HRD-1 sensitizers. The photovoltaic parameters including the short circuit current density $\left(\mathrm{J}_{\mathrm{sc}}\right)$, open circuit voltage $\left(\mathrm{V}_{\mathrm{oc}}\right)$, fill factor $(\mathrm{FF})$ and the power conversion efficiency (PCE) corresponding to the DSSCs are summarized in Table 2. It can be seen that DSSC based on m-HRD-1 dye shows higher photovoltaic performance than the standard N719 dye device. The observed power conversion efficiency is found to be $6.10 \%$ under 1.0 sun irradiation $\left(\mathrm{J}_{\mathrm{SC}}=18.15 \mathrm{~mA} / \mathrm{cm}^{2}, \mathrm{~V}_{\mathrm{OC}}=705 \mathrm{mV}, \mathrm{ff}=0.48\right)$ using m-HRD-1. Whereas, the device based on $\mathrm{N} 719$ sensitizer $\left[\mathrm{J}_{\mathrm{sc}}=14.07 \mathrm{~mA} \mathrm{~cm}^{-2}, \mathrm{~V}_{\mathrm{oc}}\right.$ $=668 \mathrm{mV}$, and $\mathrm{ff}=0.49$ ] shows a photovoltaic conversion efficiency of $4.70 \%$. The m-HRD-1 dye based device shows $20 \%$ increase in short circuit current due to the better anchoring of dye molecules and thus an increase in overall conversion efficiency.

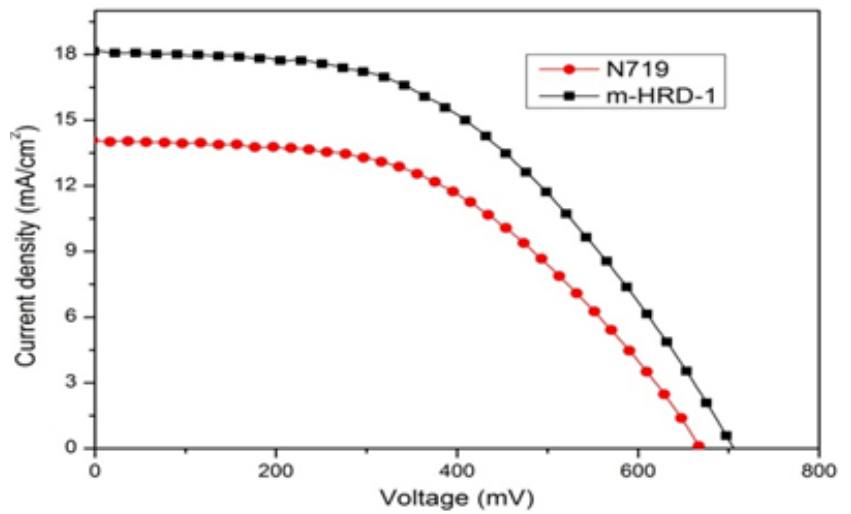

Figure 5 Comparison of J-V characteristics of DSSCs based on standard N719 and m-HRD-I sensitizers.

Table 2 Photovoltaic parameters of the DSSCs based on N7 I9 and m-HRD-I sensitizers ${ }^{\mathrm{a}}$

\begin{tabular}{lllll}
\hline & $J_{\text {sc }}$ & $\mathbf{V}_{\text {oc }}$ & FF & Efficiency \\
\hline Sensitiser & {$\left[\mathrm{mA} / \mathrm{cm}^{2}\right]$} & {$[\mathrm{mV}]$} & {$[\%]$} & {$[\%]$} \\
\hline N719 & 14.07 & 668 & 49 & 4.7 \\
m-HRD-I & 18.15 & 705 & 48 & 6.1
\end{tabular}

aphotoelectrode: $\mathrm{TiO}_{2}\left(8+4 \mu \mathrm{m}\right.$ and $\left.0.2826 \mathrm{~cm}^{2}\right)$.

bError limits: $J_{S c}: \pm 0.2 \mathrm{~mA} / \mathrm{cm}^{2}, V_{o c}= \pm 30 \mathrm{mV}, \mathrm{ff}= \pm 0.3 \%$.

\section{Thermal studies}

We examined the thermal stability of the new ruthenium (II) polypyridyl sensitizer and compared it to the thermal stability the standard sensitizer N719, using thermo gravimetric analysis. Figure 6 shows the thermal behavior of m-HRD-1, clearly indicating that the sensitizer m-HRD-1 is stable up to $270{ }^{\circ} \mathrm{C}$. The initial weight loss between 250 to $290{ }^{\circ} \mathrm{C}$ is attributed to the removal of the carboxyl group. In contrast, the standard sensitizer N719 is stable up to $200^{\circ} \mathrm{C}$.

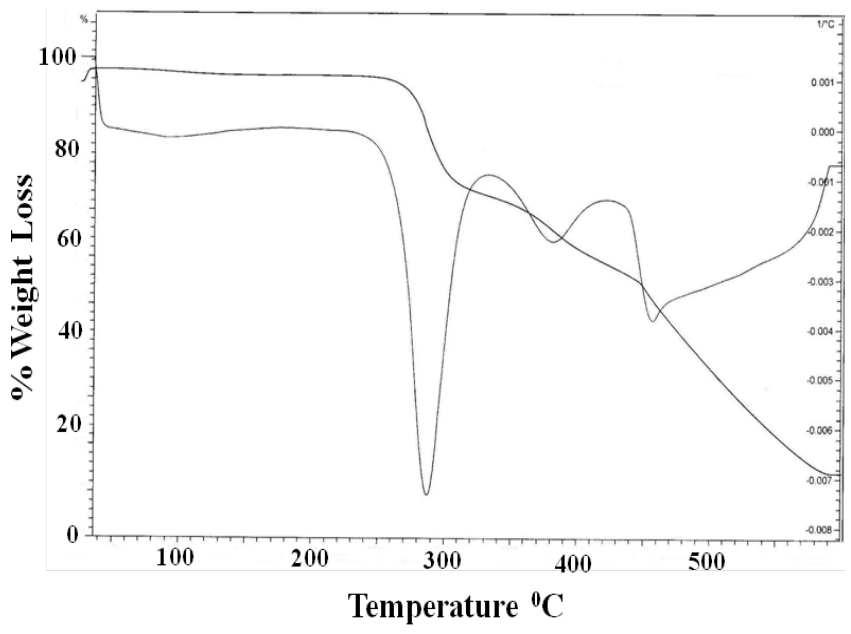

Figure $6 \mathrm{TG} / \mathrm{DTG}$ curves of $\mathrm{m}-\mathrm{HRD}-\mathrm{I}$ with heating rate of $10^{\circ} \mathrm{C} \mathrm{min}^{-1}$ under nitrogen.

\section{Conclusion}

In conclusion, we designed and synthesized a new heteroleptic Ruthenium (II) polypyridyl complex having an extended $\pi$-conjugation. The complex m-HRD-1 was characterized by various spectroscopic techniques. Both elemental analysis and ESIMS confirmed the presence of one TBA molecule in its molecular structure. MLCT band of m-HRD-1 was observed at $538 \mathrm{~nm}$ in DMF solvent. The emission spectra of m-HRD-1 quenched when adsorbed on $\mathrm{TiO}_{2}$ film as a consequence of electron transfer. Finally, we tested the performance of m-HRD-1 in dye-sensitized solar cells using $\mathrm{I} /$ $\mathrm{I}_{3}^{-}$redox couple and compared to that of the standard sensitizer N719. Thermal studies of m-HRD-1 complex suggested that it was stable up to $270{ }^{\circ} \mathrm{C}$, which was better thermal stable than standard N719 sensitizer.

\section{Acknowledgments}

The authors are thankful to DST (India)-EPSRC (UK) ('APEXII') programme and the EPSRC Supergen programme for financial support of this work.

\section{Conflicts of interest}

The author declares there is no conflict of interest.

\section{References}

1. O’Regan B, Grätzel M. A Low-Cost, High-Efficiency Solar Cell Based on Dye-Sensitized Colloidal TiO, Films. Nature. 1991;353: 737-740.

2. Nazeeruddin MK, Pechy P, Renouard T, et al. Engineering of efficient panchromatic sensitizers for nanocrystalline $\mathrm{TiO}(2)$-based solar cells. $J$ Am Chem Soc. 2001;123(8):1613-1624.

3. Bowers JW, Upadhyaya HM, Calnan S, et al. Development of Nano$\mathrm{TiO} 2$ dye sensitised solar cells on high mobility transparent conducting oxide thin films. Prog Photovoltaics: Research \& Applications. 2009; 17(4):265-272.

4. Yao Z, Zhang M, Wu H, et al. Donor/acceptor indenoperylene dye for highly efficient organic dye-sensitized solar cells. J Am Chem Soc. 2015;137(11):3799-3802. 
5. Han L, Islam A, Chen $\mathrm{H}$, et al. High-efficiency dye-sensitized solar cell with a novel co-adsorbent. Energy Environ Sci. 2012;5(3):6057-6060.

6. Mathew S, Yella A, Gao P, et al. Dye-sensitized solar cells with $13 \%$ efficiency achieved through the molecular engineering of porphyrin sensitizers. Nat Chem. 2014;6(3):242-247.

7. Robertson N. Optimizing dyes for dye-sensitized solar cells. Angew Chem Int Ed Engl. 2006;45(15):2338-2345.

8. Pearson P, Bond AM, Deacon GB, et al. Synthesis and characterisation of $\quad$ bis(2,2'-bipyridine)(4-carboxy-4'-(pyrid-2-ylmethylamido)-2,2'bipyridine)ruthenium(II) di(hexafluorophosphate): Comparison of spectroelectrochemical properties with related complexes. Inorg Chim Acta. 2008;361(3):601-612.

9. Grätzel M. Recent advances in sensitized mesoscopic solar cells. Acc Chem Res. 2009;42(11):1788-1798.

10. Song W, Chen Z, Brennaman MK, et al. Making solar fuels by artificial photosynthesis. Pure Appl Chem. 2011;83(4):749-768.

11. Giribabu L, Sudhakar K, Velkannan V. Phthalocyanines: potential alternative sensitizers to $\mathrm{Ru}(\mathrm{II})$ polypyridyl complexes for dye-sensitized solar cells. Current Sci. 2012;102(7):991-1000.

12. Giribabu L, Kanaparthi RK, Velkannan V. Molecular engineering of sensitizers for dye-sensitized solar cell applications. Chem Rec. 2012;12(3):306-328.

13. Kanaparthi RK, Kandhadi J, Giribabu L. Metal-free organic dyes for dyesensitized solar cells: recent advances. Tetrahedron. 2012;68(40):83838393.

14. Ye $M$, Wen $X$, Wang $M$, et al. Recent advances in dye-sensitized solar cells: from photoanodes, sensitizers and electrolytes to counter electrodes. Materials Today. 2015;18(3):155-162.

15. Sugathan V, John E, Sudhakar K. Recent improvements in dye sensitized solar cells: A review. Renewable \& Sustainable Energy Rev. 2015;52:5-64

16. Li F, Collins JG, Keene FR. Ruthenium complexes as antimicrobial agents. Chem Soc Rev. 2015;44(8):2259-2942.

17. Nazeeruddin MK, Kay A, Rodicio I, et al. Conversion of light to electricity by cis-X2bis(2,2'-bipyridyl-4,4'-dicarboxylate)ruthenium(II) chargetransfer sensitizers (X $=\mathrm{Cl}-, \mathrm{Br}-, \mathrm{I}-, \mathrm{CN}-$, and $\mathrm{SCN}-)$ on nanocrystalline titanium dioxide electrodes. J Am Chem Soc. 1993;115(14):6382-1690.

18. Wang P, Zakeeruddin SM, Moser JE, et al. A stable quasi-solid-state dye-sensitized solar cell with an amphiphilic ruthenium sensitizer and polymer gel electrolyte. Nat Mater. 2003;2(6):402-407.

19. Wang P, Zakeeruddin SM, Moser JE, et al. Stable New Sensitizer with Improved Light Harvesting for Nanocrystalline Dye-Sensitized Solar Cells ${ }^{\dagger}$. Advanced Materials. 2003;16(20):1806-1811.

20. Wang P, Klein C, Humphry BR, et al. A high molar extinction coefficient sensitizer for stable dye-sensitized solar cells. $J$ Am Chem Soc. 2005;127(3):808-809.

21. Karthikeyan CS, Wietasch H, Thelakkat M. Highly Efficient Solid-State Dye-Sensitized TiO2 Solar Cells Using Donor-Antenna Dyes Capable of Multistep Charge-Transfer Cascades. Adv Mater. 2007;19(8):1091-1095.

22. Giribabu L, Ch Kumar V, Ch Rao S, et al. High molar extinction coefficient amphiphilic ruthenium sensitizers for efficient and stable mesoscopic dye-sensitized solar cells. Energy Environ Sci. 2009;2(7):770-773.

23. Giribabu L, Singh VK, Ch Vijay K, et al. Organic-Ruthenium(II) Polypyridyl Complex Based Sensitizer for Dye-Sensitized Solar Cell Applications. Adv Opto Electronics. 2011. p. 8.
24. Chandrasekharam M, Rajkumar G, Suresh T, et al. Substitution of Carbazole Modified Fluorenes as $\pi$-Extension in $\mathrm{Ru}(\mathrm{II})$ ComplexInfluence on Performance of Dye-Sensitized Solar Cells. Adv Opto Electronics. 2012. p. 10

25. Chen $\mathrm{CY}, \mathrm{Wu} \mathrm{SJ}, \mathrm{Wu} \mathrm{CG}$, et al. A ruthenium complex with superhigh light-harvesting capacity for dye-sensitized solar cells. Angew Chem Int Ed Engl. 2006;45(35):5822-5825.

26. Gao F, Wang Y, Shi D, et al. Enhance the optical absorptivity of nanocrystalline $\mathrm{TiO}_{2}$ film with high molar extinction coefficient ruthenium sensitizers for high performance dye-sensitized solar cells. $\mathrm{J} \mathrm{Am} \mathrm{Chem}$ Soc. 2008;130(32):10720-10728.

27. Giribabu L, Bessho T, Srinivasu M, et al. A new family of heteroleptic ruthenium(II) polypyridyl complexes for sensitization of nanocrystalline TiO 2 films. Dalton Trans. 2011;40(17):4497-4504.

28. Giribabu L, Singh VK, Srinivasu M, et al. Synthesis and photo electrochemical characterization of a high molar extinction coefficient heteroleptic ruthenium(II) complex. J Chem Sci. 2011;123(4):371-378.

29. Jella T, Srikanth M, Bolligarla R, et al. Benzimidazole-functionalized ancillary ligands for heteroleptic $\mathrm{Ru}(\mathrm{II})$ complexes: synthesis, characterization and dye-sensitized solar cell applications. Dalton Trans. 2015;44(33):14697-14706.

30. Wadsworth WS, Emmons WD. The Utility of Phosphonate Carbanions in Olefin Synthesis. J Am Chem Soc. 1961;83(7):1733-1738.

31. Adamo C, Barone V. Toward reliable density functional methods without adjustable parameters: The PBE0 model. $J$ Chem Phys. $1999 ; 110(13): 6158$

32. Hay PJ, Wadt WR. Ab initio effective core potentials for molecular calculations. Potentials for the transition metal atoms Sc to Hg. J Chem Phys. 1985;82(1):270

33. Wadt WR, Hay PJ. Ab initio effective core potentials for molecular calculations. Potentials for main group elements $\mathrm{Na}$ to Bi. J Chem Phys. 1985;82(1):284

34. Hay PJ, Wadt WR. Ab initio effective core potentials for molecular calculations. Potentials for $\mathrm{K}$ to $\mathrm{Au}$ including the outermost core orbitals. J Chem Phys. 1985;82(1):299-310.

35. Krishnan R, Binkley JS, Seeger R, et al. Self-consistent molecular orbita methods. XX. A basis set for correlated wave functions. J Chem Phys. $1980 ; 72: 650$

36. Clark T, Chandrasekhar J, Spitznagel GW, et al. Efficient diffuse functionaugmented basis sets for anion calculations. III. ${ }^{\dagger}$ The $3-21+\mathrm{G}$ basis set for first-row elements, Li-F. J Comp Chem. 1983;4(3):294-301.

37. Cossi M, Rega N, Scalmani G, et al. Energies, structures, and electronic properties of molecules in solution with the C-PCM solvation model. $J$ Comput Chem. 2003;24(6):669-681.

38. Yanai T, Tew DP, Handy NC. A New Hybrid Exchange-Correlation Functional Using the Coulomb-Attenuating Method (CAM-B3LYP). Chem Phys Lett. 2004;393(1-3):51-70.

39. Peach MJG, Benfield P, Helgaker T, et al. Excitation energies in density functional theory: an evaluation and a diagnostic test. J Chem Phys. 2008;128(4):044118

40. Frisch MJ, GW Trucks, HB Schlegel. Gaussian09 Revision C.01, Gaussian, Inc., Wallingford, England, CT. 2010.

41. Reeta PS, Giribabu L, Senthilrasu S, et al. Ethynyl thiophene-appended unsymmetrical zinc porphyrin sensitizers for dye-sensitized solar cells RSC Adv. 2004;4(27):14165-14175. 
42. Narra VK, Ullah $H$, Singh VK, et al. D- $\pi$-A system based on zinc porphyrin dyes for dye-sensitized solar cells: Combined experimental and DFT-TDDFT study. Polyhedron. 2015;100:313-320.

43. Norio M, Suzuki A. Stereoselective synthesis of arylated (E)-alkenes by the reaction of alk-1-enylboranes with aryl halides in the presence of palladium catalyst. Chem Commun. 1979;(19):866-867.
44. Hegfeldt A, Grätzel M. Light-Induced Redox Reactions in Nanocrystalline Systems. Chem Rev. 1995;95(1):49-68.

45. Nazeeruddin MK, Besho T, Cevey L, et al. A high molar extinction coefficient charge transfer sensitizer and its application in dye-sensitized solar cell. J Photochem Photobiol A: Chemistry. 2007;185(2-3):331-337. 